"Banking competition and misconduct: how dire economic conditions affect banking behavior"

Ezelda Swanepoel id https://orcid.org/0000-0002-2045-0880

AUTHORS

Ja'nel Esterhuysen

Gary van Vuuren (iD https://orcid.org/0000-0001-6811-0538

Ronnie Lotriet

Ezelda Swanepoel, Ja'nel Esterhuysen, Gary van Vuuren and Ronnie Lotriet

ARTICLE INFO (2016). Banking competition and misconduct: how dire economic conditions affect banking behavior. Banks and Bank Systems, 11(4), 31-39. doi:10.21511/bbs.11(4).2016.03

DOI http://dx.doi.org/10.21511/bbs.11(4).2016.03

RELEASED ON

Friday, 09 December 2016

JOURNAL

"Banks and Bank Systems"

FOUNDER

LLC "Consulting Publishing Company "Business Perspectives"

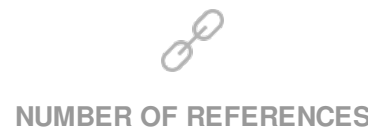

0
NUMBER OF FIGURES

0

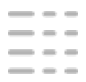

NUMBER OF TABLES

0

(C) The author(s) 2022. This publication is an open access article. 
Ezelda Swanepoel (South Africa), Ja'nel Esterhuysen (South Africa), Gary van Vuuren (South Africa), Ronnie Lotriet (South Africa)

\title{
Banking competition and misconduct: how dire economic condi- tions affect banking behavior
}

\begin{abstract}
Increasingly, in the last decade, largely due to perceived greater shareholder pressures for more profitable performance, compensation maximization has taken center stage in some segments of the banking industry. Banks need to establish board governance committees with explicit responsibilities to monitor corporate ethics and culture. This paper aims to measure the correlation between dire economic conditions, competition, banking profitability, and misconduct. This is done by means of GDP comparisons to determine economic conditions, calculating z-scores to determine bank risk taking, and analysis of variance of return on assets, return on equity and z-scores, to determine profitability, and fines comparisons to determine misconduct. Analysis finds that dire economic conditions may lead to increased competition, increased competition may lead to increased risk taking, increased risk taking may have an impact on a bank's financial performance, and decreased financial performance may lead to increase in misconduct.
\end{abstract}

Keywords: banking competition, banking behavior, economic conditions.

JEL Classification: C21, G01, G21, G32.

\section{Introduction}

Between 2007 and 2009, world financial markets were in the midst of a credit crisis of historic breadth and depth, which began as a result of consumer defaults on subprime mortgages widely viewed as the worst financial crisis since the Great Depression of 1929 (Ivashina \& Scharfstein, 2010).

This credit crisis raised concerns about the solvency and liquidity of financial institutions worldwide with the failures of Lehman Brothers and Washington Mutual, in addition to government takeovers of Fannie Mae, Freddie Mac and AIG, in the largest bank failure in United States (US) history. As a result, global credit markets halted and unprecedented government intervention worldwide was required (Duchin et al., 2010; Erkens et al., 2012).

Furthermore, at the onset of the credit crisis, with the collapse of Lehman Brothers and Washington Mutual, liquidity concerns drew public scrutiny towards the London Interbank Offer Rate (LIBOR). At that time, the perceived default and liquidity risks of banks rose significantly, driving up LIBOR (Brunnermeier, 2009). Hence, the LIBOR rate in January 2008 for onemonth LIBOR was set at $3.14 \%$, for threemonths was $3.11 \%$, for six months was $3.04 \%$, and for 12 months was $2.85 \%$ (BBC News, 2013). However, evidence surfaced as early as 2005 that Barclays, a United

(C) Ezelda Swanepoel, Ja'nel Esterhuysen, Gary van Vuuren, Ronnie Lotriet, 2016.

Ezelda Swanepoel, Lecturer, School of Economic Sciences, North-West University, South Africa.

Ja'nel Esterhuysen, Research Fellow, NWU School of Economics, North West University, South Africa

Gary van Vuuren, Visiting Professor, NWU School of Economics, North West University, South Africa.

Ronnie Lotriet, Associate Professor, NWU School of Business and Governance, North-West University, South Africa.
Kingdom (UK) based bank, had attempted to manipulate the dollar LIBOR and European Interbank Offer Rate (EURIBOR) rates at the request of its derivative traders (Das, 2012; BBC News, 2013). As the collapse of Lehman Brothers and Washington Mutual caused liquidity concerns which increased LIBOR, reflecting the true nature of the health of the banking sector, the manipulation from Barclays was, in turn, an attempt to distort this reality, claiming the banking sector was in better condition than it actually was.

Consequently, LIBOR has been termed the world's most important number and is the primary benchmark for global short-term interest rates (Abrantes-Mentz \& Evans, 2012). As a result, it can be inferred that manipulation of this primary benchmark in a banks' favor could yield extreme benefits. This was the case in June 2012, when the UK and the United States (US) authorities fined Barclays $£ 290$ million for manipulating LIBOR and EURIBOR (Das, 2012; Eisl et al., 2013).

In addition to the credit crisis (2007/9) and the LIBOR and EURIBOR manipulation, concerns with regard to customer protection, as well as banker's behavior have come to prominence in financial regulation in the last decade. From 2005 onwards, when the Financial Services Authority (FSA) assumed their relevant statutory mandate, it has been grappling with the problem of the mis-selling of Payment Protection Insurance (PPI). PPI related uses have also been a major concern for the Financial Ombudsman Service (FOS). During 2011 alone, the industry paid out around $£ 1.9$ billion by way of redress to consumers who were mis-sold PPI (Campbell, 2006; Inderst, 2009). However, the Financial Conduct Authority (FCA) estimates the likely total figure to be in the region of $£ 9$ billion (FCA, 2015). 
More recently, a number of investigations have been launched in the US and UK by regulatory agencies and central banks into the alleged manipulation of the foreign exchange (Forex) market. The Forex market involves daily transactions between financial institutions that accounts for $\$ 5.3$ trillion (tn) in transactions every day, more than 20 times the size of the global stock and bond market (Ryder, 2014). This may have come as a surprise to regulators, as the Forex market has been considered by regulators too big to manipulate, hence, it has been largely unregulated (BBC News, 2014; Ryder, 2014).

The paper contributes to the literature in several ways. It details the different banking scandals which include the LIBOR, EURIBOR, Credit crisis of (2007/09), PPI and the Forex scandals. In addition, it details the relationship between competition, misconduct, and fines imposed in the US and UK banking industry. However, the main contribution is the calculated correlation between how difficult financial times lead to increased competition, hence, increased risk taking and, thus, misconduct in banking. The paper also makes mention of the efficiency of the z-score as a manner in which risk can be measured.

The paper proceeds as follows: section 1 provides a literature study detailing the different scandals with focus on US and UK banks, while section 2 details the correlation between competition, fines imposed, and misconduct, pre- and post the credit crisis in banking. Section 3 details the methodology used. Section 4 presents and discusses the results obtained. Final section concludes and highlights the implications and future direction for research.

\section{Literature review}

Increasingly, in the last decade, largely due to perceived greater shareholder pressures for more profitable performance, as well as increased competition to hire talent, compensation maximization has taken center stage in some segments of the banking industry (Rhodes, 2015). Hence, it has become imperative to strengthen the accountability of managers. Therefore, new frameworks are put in place to enhance the accountability of managers for activities that not only relate to credit, market and operational risk, but also to all aspects of reputational risk. Banks need to establish board governance committees with explicit responsibilities to monitor corporate ethics and culture (Rhodes, 2015).

Much of the commentary and analysis about the actions of financial institutions, from the credit crisis to events such as product mis-selling, the recent LIBOR, EURIBOR and Forex scandals all share a common and fundamental focus - weaknesses in the cultures of banks and other financial institutions. In addition, there is enormous public skepticism that the leaders of banks will take decisive actions that deliver real cultural change. Even so, further misdeeds will assuredly prompt authorities to impose even greater fines and shareholders will not take this lightly (Rhodes, 2015).

1.1. Credit crisis (2007/09). Motivated by the significance of the credit crisis, an emerging body of literature (e.g., Bruner, 2011; Safian, 2011; Erkens et al., 2012) has identified and examined certain macroeconomic factors. These factors formed the roots of the credit crisis and affected all firms, however, some more than others. Studies in this regard (e.g., Kirkpatrick, 2009; Aebi et al., 2012; Erkens et al., 2012) argue that firms' risk management and financial policies have a significant impact on the degree to which firms were impacted by the credit crisis. As a result, the Organization for Economic Co-operation and Development (OECD) has pinpointed failures in risk management as the most important cause of the credit crisis and has noted that this failure was attributed to weakness in corporate governance more than to defaulting risk assessment or risk models (Brunnermeier, 2009; Kirkpatrick, 2009).

In addition, as a result of the credit crisis, the credit quality of European and US banks deteriorated substantially. Hence, US financial institutions have seen enormous declines in capital related to write-downs of bad loans and plummeting values of collateral debt obligations (CDOs). These huge losses have resulted in an increased interest in risk management on the part of financial institutions, and have lowered both their capacity and willingness to take on risk. Evidence of tighter lending standards and withdrawn lines of credit abounds (Duchin et al., 2010; Fukuda, 2012).

Figure 1 graphs the quarterly dollar volume of loan issuances from 2000 through 2008. The decline in new loans accelerated during the banking panic. The dollar volume of bank loans declined from $\$ 701 \mathrm{bn}$ in the second quarter of 2007, the peak of the credit boom, to $\$ 281$ bn in the third quarter of 2008. Three months later, in the third quarter of 2008, it declined even further to $\$ 150 \mathrm{bn}$. This decline in loans could lead to competition between banks, as shareholders still demand returns (Ivashina \& Scharfstien, 2010).

1.2. LIBOR and EURIBOR. LIBOR originally reflected rates at which banks in the Euro-Dollar market lent surplus liquidity to one other, the interbank rates offered. As the market grew, an accepted pricing benchmark was required. Consequently, the British Bankers Association (BBA) together with major global financial institutions and regulators, primarily the Bank of England (BoE), created the BBA rates. Initially, these rates were standard only for interest rate swaps (IRS). An IRS is an agreement in which two counter- 
parties agree to periodically exchange fixed and floating rates of interest over a number of periods of time (Gottesman, 2016). However, demand for a standard benchmark for financial instruments, based on money market rates, led to the creation of the BBA LIBOR fixings. This officially commenced on the $1^{\text {st }}$ of January 1986 (Abrantes-Mentz \& Evans, 2012; Das, 2012).

Since 1986, LIBOR has become integrated into the majority of the world's financial products, and currently provides the reference point for nearly all interest rate derivatives and variable rate loans available in the European financial markets (AbrantesMentz \& Evans, 2012). LIBOR rates are used as a benchmark to set payments on roughly $\$ 800$ trillion-worth of financial instruments, which range from complex interest rate derivatives to simple mortgages (Fukuda, 2012; Koblenz et al., 2013). LIBOR is currently calculated for fifteen different loan durations, which range from overnight to a year and in 10 currencies (Abrantes-Mentz \& Evans, 2012; Ryder, 2014).

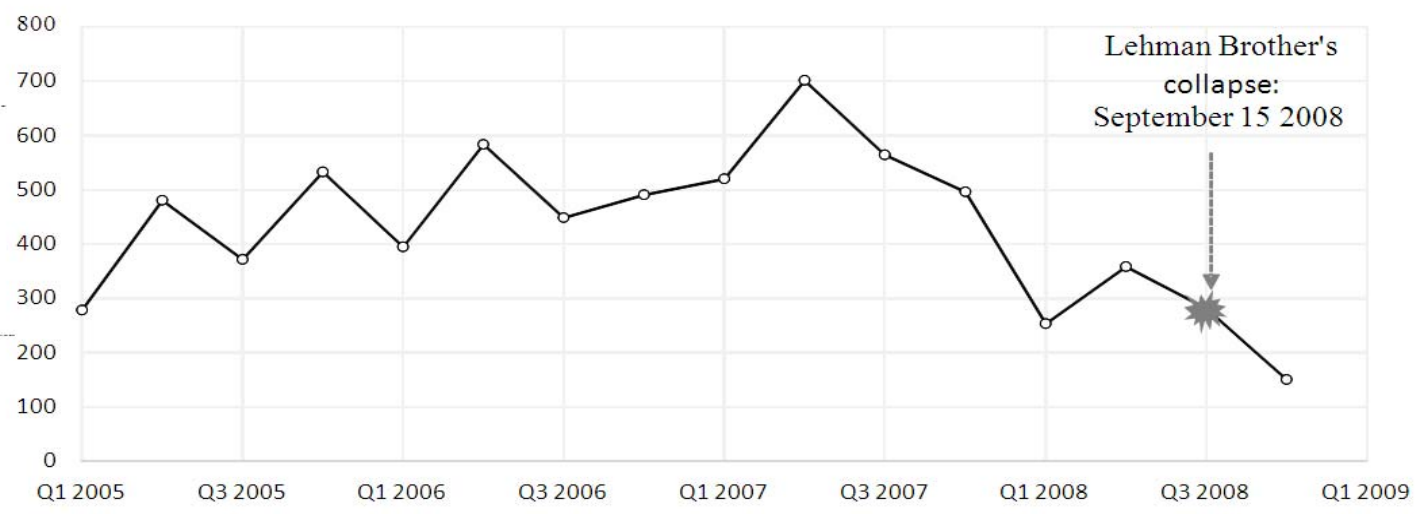

Fig. 1. Total US\$ amount of loans issued from 2005 to 2008

Source: Ivashina \& Scharfstien (2010).

LIBOR is supposed to measure the rate at which large banks borrow unsecured funds from one another at various short-term maturities, and for a variety of currencies (Ryder, 2014). Moreover, the rate signals a bank's health to financial markets, rising when a bank is in trouble, and creates the basis for payments on trillions of dollars in corporate debt, home mortgages, and financial contracts worldwide. Hence, the impact of even small rate shifts can be critical (Koblenz et al., 2013). Therefore, due to its pervasiveness in, and significance for the financial markets, the rate has come to be known as "the world's most important number". Unfortunately, there is a growing evidence that certain banks have manipulated LIBOR both individually and through coordinated behavior (Abrantes-Mentz \& Evans, 2012; Koblenz et al., 2013).

In point of fact, by the spring of 2012, US and UK investigators had uncovered substantial (Koblenz et al., 2013) evidence that Barclays and several other banks manipulated LIBOR. Included in this evidence were emails of Barclays derivatives traders who made a total of 257 requests to fix LIBOR and EURIBOR rates (FSA, 2012). In June 2012, following an extensive investigation, Barclays admitted to misconduct. Again, Barclays' unethical LIBOR submissions were to create the impression that the bank's financial position was better than it actually was. In July 2012, the UK's Serious Fraud Office (SFO) launched a criminal investigation into the
LIBOR scandal. The SFO investigated a total of eighteen banks which include Citigroup, Inc.; Royal Bank of Scotland; UBS; Lloyds Banking group and Deutsche Bank (Koblenz et al., 2013).

1.3. Payment Protection Insurance (PPI). A PPI policy provides insurance against a borrower who might become unable to make credit payments for specified reasons (Campbell et al., 2011). This includes accidents, sickness, unemployment and death. As with any other type of insurance, PPI terms may include or impose restrictive conditions on particular types of claimant or claim, and may be subject to other terms and limit the quality of the cover provided (Campbell et al., 2011; Ferran, 2011).

Consumers who may be ignorant to understand complicated financial contracts can become particularly vulnerable to mis-selling by distributors incentivised by remuneration structures to push financial products, irrespective of product suitability for the customer (Campbell, 2006; Inderst, 2009; Campbell et al., 2011; Mullainathan et al., 2012; Beyer et al., 2013).

As the credit crisis caused an increase in competition and incentives to chase high targets enjoyed before the credit crisis remained, employees were eager and willing to push financial products. In addition, employees were rewarded with certain practices which include "champagne bonuses" and "a grand in your hand" for reaching targets. Accordingly, in December 2011, HSBC was fined $£ 10.5$ million by the FSA 
and undertook to make redress for the mis-selling of unsuitable asset-backed investment products to fund long-term care costs for elderly customers. In addition, in January 2011, Barclays was fined $£ 7.7$ million by the FSA and needed to pay roughly $£ 60$ million redress for suitability and related compliance failures in respect of the selling of balanced income and cautious income funds to customers who were mostly retired or nearing retirement (Ferran, 2011; Mullainathan et al., 2012; Beyer et al., 2013).

1.4. Foreign exchange markets (Forex). Rapidly changing prices in the Forex market make it difficult to establish the going rate for particular currencies at any one time. Therefore, in order to facilitate businesses and investors to value their multicurrency assets and liabilities, cross rates for ten major currencies are fixed. This is based on actual currency deals that take place in a window 30 seconds before and 30 seconds after $4 \mathrm{pm}$ London time. WM Reuters calculates the fix rates based on observed transactions, which form the benchmarks for that day (BBC News, 2014; Goodway, 2014).

Clients of banks regularly put in orders to buy or sell currencies at the fix rate ahead of it being fixed. A bank with net client orders to buy a currency at the fixed rate will make a profit if the average rate at which it buys the currency in the market is lower than the rate at which it sells to the clients. Banks can legitimately manage their currency book to try and improve the changes of this being the case (BBC News, 2014; Goodway, 2014).

However, as clients put in orders to buy a currency at the fix rate ahead of it being fixed, most banks saw a golden opportunity to manipulate Forex market, since the market is unregulated, as it accounts for $\$ 5.3 \mathrm{tn}$ in transactions each day and was considered too big to manipulate. The enormity of the market accounted for the fines being four times larger than those imposed following the LIBOR scandal. Six banks (JP Morgan Chase, Citigroup, Bank of America, UBS, RBS, and HSBC) have been fined $£ 1.1$ billion by the FCA, and $£ 880$ million by the Commodity Futures Trading Commission (CFTC) (BBC News, 2014; Ryder, 2014).

\section{Competition, misconduct, and fines imposed}

Historically, the banking industry has been exempt from the strict application of a competition policy. Competition was undesirable, given its responsibility for instabilities in the banking system. However, this perception has been somewhat revised (Hasan \& Marinc, 2013).
An efficient financial system allocates resources with as little costs as possible (Hasan \& Marinc, 2013). Competition helps to achieve this efficiency, particularly cost efficiency. Some studies (e.g., Stiroh \& Strahan, 2003; Evanoff \& Ors, 2008) find that competition among banks is good for the industry and the economy. Higher competition positively affects not only the efficiency of the banking industry, but also the productivity of the real economy. Several studies (e.g., Dell'Ariccia \& Marquez, 2006; Boot \& Marnic, 2009) also indicate that competition enhances monitoring and, consequently, credit allocation (Hasan \& Marinc, 2013).

The key issue with the nexus of competition and stability in banking relates to the manner in which competition interferes with banking during bad economic periods when bank failures may have dire repercussions for an entire economy. Stability in banking during bad times is a major concern, and government or regulatory intervention becomes crucial to prevent bank failures. Therefore, in the face of a financial crisis, competition must not create a situation where long-term damage of the economy results. Therefore, enhanced regulatory and supervisory frameworks are required to facilitate competition. However, the problem is that the financial industry is already overregulated (Hasan \& Marinc, 2013).

These regulatory and supervisory frameworks were either not in place or not effective enough to mitigate long-term competitive distortions which resulted in banking misconduct, eventually leading to banking failures. In addition, during the credit crisis, bank supervisors lacked tools to restructure failing banks successfully. The fragmented supervisory structure aggravated the problem, and the pressure on financial stability mounted, triggering intervention by national governments, which supported failing banks mainly through a wide framework of state aid. As stated, in times of financial crisis, competition needs to deviate from the standard case scenario and support interventions necessary for the stability of the financial system. However, as a result of either the lack of supervisory competitive frameworks or the absence there of, misconduct mounted, as each bank fought for fair share in the market (Hasan \& Marinc, 2013). In consequence, Propositions (1); (2); (3); and (4) can be formulated:

Proposition (1): Difficult financial times could result in increased competition.

Proposition (2): Increased competition may result in increased risk taking.

Proposition (3): Risk taking levels could have an impact on bank's financial performance.

Proposition (4): Decreased financial performance may result in increased misconduct. 


\section{Research methodology}

3.1. Profitability. ROA and ROE are a comprehensive measures of bank profitability (Athanasoglou et al., 2008; Garcia-Harrero et al., 2009; Tarrif \& Majeske, 2013). Both these measures will be used, because banks that rely heavily on deposits and borrowings rather than on stakeholders' equity to support assets tend to have higher ROE than those that do not. There are no set benchmarks for ROA and ROE, however, it is evident that higher returns indicate greater profitability (Tarrif \& Majeske, 2013).

3.2. Stability. Risk taking can be measured by means of z-scores developed by Roy (1952), Hannan \& Hanweck (1998), and De Nicolo (2000). The z-score is a measure of bank stability and indicates the distance from insolvency. It combines accounting measures of profitability, leverage, and volatility. Specifically, insolvency can be defined as a state where losses surmount equity $(E>\pi)$, where $E$ is equity and $\pi$ is profit. The probability of insolvency can be expressed as prob (-ROA < CAR), where ROA is return on assets calculated as $\pi / A$ and CAR is the capital-to-asset ratio calculated as $E / A$. If profits are assumed to follow a normal distribution, it can be shown that $\mathrm{z}=(\mathrm{ROA}+\mathrm{CAR}) / \mathrm{SD}(\mathrm{ROA})$ which is the inverse of the probability of insolvency (Brandao-Marques et al., 2013; Mirzaei, 2013). More specifically, the zscore indicates the number of standard deviations that a bank's ROA has to fall below its expected value before equity is depleted and the bank is insolvent (Roy, 1952; Hannan \& Hanweck, 1998).

Thus, a smaller z-score can be associated with narrow returns, larger return volatility, or higher leverage (Mirzaei, 2013). Moreover, an increase in the capitalto-asset ratio would raise the z-score, as would an increase in the operating return on assets. A z-score can only be calculated if the accounting information for at least four years is available.

3.2.1. Model diagnostics. As the $z$-score has been used extensively throughout literature, the importance and relevance thereof may come into question. In order to prove that this model is still very relevant, as well as accurate, a study was conducted by Chiaramonte, Croci and Poli (2015) who compared CAMELS as a measure of bank risk to the z-score. They used these tools to acquire the empirical attractiveness of the $\mathrm{z}$-score.

They found that the predictive ability of the z-scores held, even when using different computational approach, which took into account the average returns on assets over a threeyear period. They also assessed the predictive power of the $\mathrm{z}$-score according to various bank characteristics and found that the z-score was slightly more effective when the organizational and productive complexity of banks increased along with the public incentives to scrutinize bank riskiness, as it is the case for large banks. Lastly, Chiaramonte et al. (2015) maintained that the accuracy of the z-score marginally improved with respect to the whole period during the credit crisis (2007/09).

3.3. Population, sample and data collection. This study comprises two samples, as a fully systematic test of bank risk taking would require data from all international banks affected by the credit crisis and such a study is not feasible. Hence, the sample used to measure risk taking in banks focused on the largest and most publicly announced banks, as they are marked as more important than smaller banks from an economic investment perspective. The sample includes seven large international banks from the US and the UK. The financial data obtained are publicly available and were analyzed for the last 11 years (2000 to 2010).

Furthermore, the study also analyzed the fines imposed on international banks, however, the data obtained comprise the collective amount of large international banks. The data were obtained from the Financial Services Authority (FSA) and the Financial Conduct Authority (FCA). The FSA was the UK's integrated financial regulator, however, in 2010, it was stated that the FSA would be abolished and the Bank of England would be put back in charge of supervision. The FCA is responsible for consumer protection in financial services and the regulation of conduct of business, and market regulation, including the listing of securities. The FCA also assumes the responsibility for consumer credit regulation that is currently exercised by the Office of Fair Trading (Ferran, 2011). The fines table from both these authoritative bodies was analyzed, and the combined fines of all the international banks for each consecutive year were documented in Tables 4 and 5.

3.4. Data analysis. In order to test the propositions, different techniques were used. For Proposition (1): a literature review was conducted, as this can be evidenced by the significant decline in profits, confidence, and stock markets during the credit crisis. To test for Proposition (2): the z-scores for the individual banks, as well as the mean $\mathrm{z}$-score, were calculated using Microsoft Excel, as only basic descriptive statistical analyses were used.

To test for Proposition (3): the Statistical Package for Social Sciences (SPSS) was used to perform more advanced statistical analysis by means of correlation and analysis of variance (ANOVA) of ROA, ROE and $\mathrm{z}$-scores. One of the reasons for the frequency of regression of ANOVA applications is its suitability for many different types of study design. ANOVA procedures are applicable to experimental, quasiexperimental, and non-experimental data. 


\section{Results and discussion}

4.1. Descriptive statistics. Two data sets are provided. The first data set provides the descriptive statistics between 2000 and 2006, as this is the period prior to the credit crisis being officially declared by the National Bureau of Economic Research (1 December 2008). The second data set provides the descriptive statistics between 2007 and 2010, as this is when the credit crisis reached a peak. The reason for the two different timelines is to determine if the credit crisis did, in fact, cause increased risk taking by the banks.

Table 1 provides the descriptive statistics for the analyzed variables for the period between 2000 and 2006, a period which signifies high economic growth, and a period just prior to the financial crisis.
The profitability measure of ROE varies between $3.99 \%$ and $30.88 \%$ with a mean of $16.50 \%$ and a standard deviation of $5.47 \%$. Hence, the ROE measures from the various banks differ significantly.

The mean ROA is $0.93 \%$, with a standard deviation of $0.39 \%$. This indicates that $68 \%$ of the data lie within the range of $0.54 \%$ and $1.32 \%$, again indicating a large dispersion of data. The profitability as measured by ROA varies between $0.23 \%$ and $1.64 \%$. The $z-$ scores for the seven international banks vary between 0.83 and 11.04 with a standard deviation of 2.76 and a mean of 5.47. This indicates possible outliers, as the standard deviation indicates that $68 \%$ of the data lie within the range of 2.71 and 8.23 . This indicates that some banks were outperforming their counterparts.

Table 1. Descriptive statistics from 2000 to 2006

\begin{tabular}{|l|c|c|c|c|c|}
\hline & $\mathrm{N}$ & Minimum & Maximum & Mean & Std. Deviation \\
\hline ROE & 48 & 3.99 & 30.88 & 16.50 & 5.47 \\
\hline ROA & 48 & 0.23 & 1.64 & 0.93 & 0.39 \\
\hline z-scores & 48 & 0.83 & 11.04 & 5.47 & 2.76 \\
\hline
\end{tabular}

Table 2 provides the descriptive statistics for the analyzed variables between 2007 and 2010. The seven banks' profitability, as measured by ROE, varies between $-28.28 \%$ and $29.03 \%$, with a mean of $5.73 \%$ and a standard deviation of $11.39 \%$. The large standard deviation indicates the data are, to a large extent, dispersed from the mean, as $68 \%$ of the data lie between $-5.66 \%$ and $17.12 \%$, which indicates some banks were very profitable, while others were very unprofitable with regard to ROE.

$68 \%$ of the profitability of the seven banks, as measured by the ROA, varies between $-1.63 \%$ and
$1.41 \%$ during the period and has a standard deviation of $0.64 \%$. The mean ROA is $0.31 \%$. This again indicates that there was a large range of data, hence, the banks reported large differences in the values of their ROA. The mean z-score for the seven international banks between 2007 and 2010 is 1.41 , with a standard deviation of 1.46 , a minimum of -1.71 and a maximum of 4.20. Again, there was a large dispersion of data, as $68 \%$ of the data fell within the range of 0.05 and 2.87, which indicates the possibility of outliers. Hence, some banks outperformed their counterparts.

Table 2. Descriptive statistics from 2007 to 2010

\begin{tabular}{|l|c|c|c|c|c|}
\hline & N & Minimum & Maximum & Mean & Std. Deviation \\
\hline ROE & 28 & -28.28 & 29.03 & 5.73 & 11.39 \\
\hline ROA & 28 & -1.63 & 1.41 & 0.31 & 0.64 \\
\hline z-scores & 28 & -1.71 & 4.21 & 1.41 & \\
\hline
\end{tabular}

\section{Propositions testing results}

From the literature study, it is evident that difficult financial times resulted in increased competition, since competing bank's fight over the remaining profits left in the market. Furthermore, to support Proposition (1), the database is presented by the World Bank (2015) which, among many, indicates the OECD (Organization for Economic Co-operation and Development) member countries' GDP annual percentage growth rates, suggest at the decline in profits. This is depicted in Figure 2. As is evident from Figure 2, there is a decrease in GDP of OECD member countries of $2.03 \%$. A decrease in the GDP results in a decrease in economic activity, which leads to less banking or lending activity. In such a situation, it will result in increased competition to ensure shareholder value. Furthermore, from the financial statements used to calculate the z-score, the mean net income indicated a decline of US\$4.7bn or $58.45 \%$ in profits, depicted in Figure 3. Thus, the alternative Proposition (1) can be accepted.

For Proposition (2), Table 1 and Table 2 provide descriptive statistics for the periods 2000-2006 and 2007-2010, respectively. From both these tables, it is evident that risk taking did, in fact, increase during the credit crisis, as the mean zscores, which is the measure for risk taking, decreased from 5.47 to 1.41 , a decline of $74.22 \%$. Thus, the Proposition (2) can be accepted. 


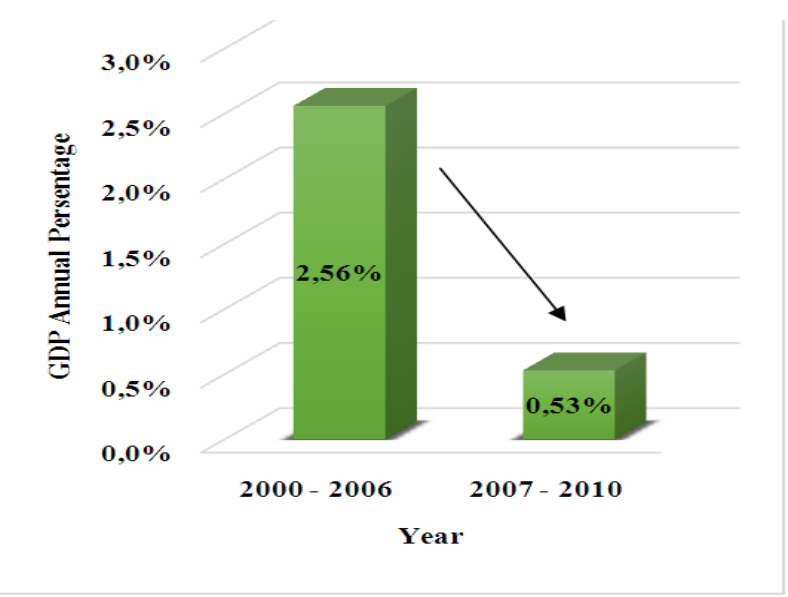

Fig. 2. OECD member countries' GDP annual percentage growth rates

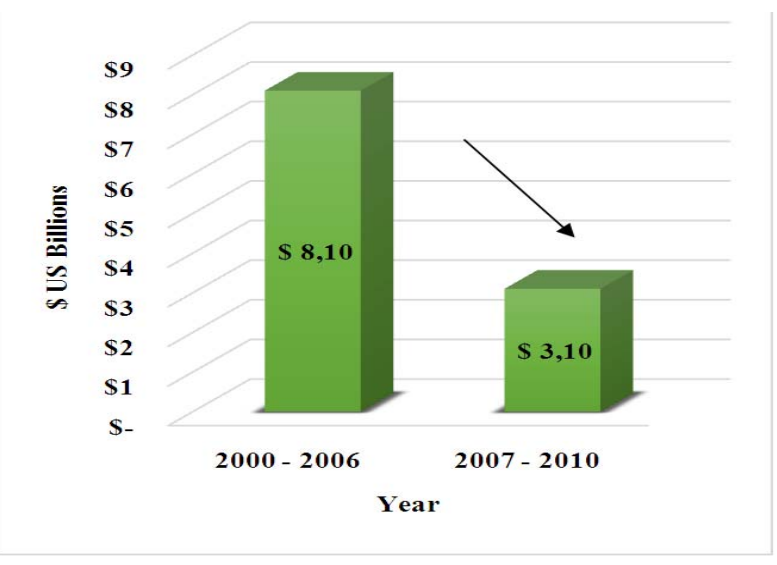

Fig. 3. Mean net income in US billions

Proposition (3) was tested using inferential statistical tests, which consisted of simple linear regression and ANOVA tests. Table 3 presents the results of regression ROA and ROE on risk taking. The re- gression analysis tested the relationship between the seven international banks' level of risk taking and average ROA and ROE to determine if risk taking affects financial performance. The data from 2007 to 2010 were used. The results show that the model with ROA and ROE as dependent variables is significant with a sig $=0.00$ with an adjusted $\mathrm{R}$ Square $=0.655$. Furthermore, the coefficient $\mathrm{z}$ scores are positive which indicate that the higher the $\mathrm{z}$-score, the higher the ROA and ROE will be.

From the results of Table 3, it can be deducted that the independent variables (ROA and ROE) describe $65.5 \%$ of the changes to the dependent variable. Further to this, the Beta values from the Coefficient table are the regression equation $\left(B_{0}=-0.11 ; B_{1}=0.21 ; B_{3}=\right.$ $5.62)$. Thus, the regression equation can be denoted as $\hat{y}=-0.11+0.21+5.62$. The Standard Error for the Constant indicates that at an $\alpha=0.05$ and degrees of freedom (df) of 45 , the Beta of -0.11 falls between the range of -1.452 and 1.452 . This was calculated with a critical value of 2.021. Taking $\alpha=0.05$ with df of 45 and a critical value of 2.021 this can be computed for all the variables.

The $t$ value is derived by dividing the Beta with the Standard Error. This value is used to determine if the data are statistically significant. However, the data analysis provided Sig. values and, with a Sig value $<$ 0.05 , the data are statistically significant. From this, it is evident that risk taking is a significant predictor of ROE with a sig $=0.00$, however, risk is not a significant predictor of ROA with a sig $=0.692$. This would suggest that risk taking levels do have an impact on a bank's financial performance, but only within the limits of this study, on ROE.

Table 3. Regression and ANOVA of ROA and ROE on z-scores

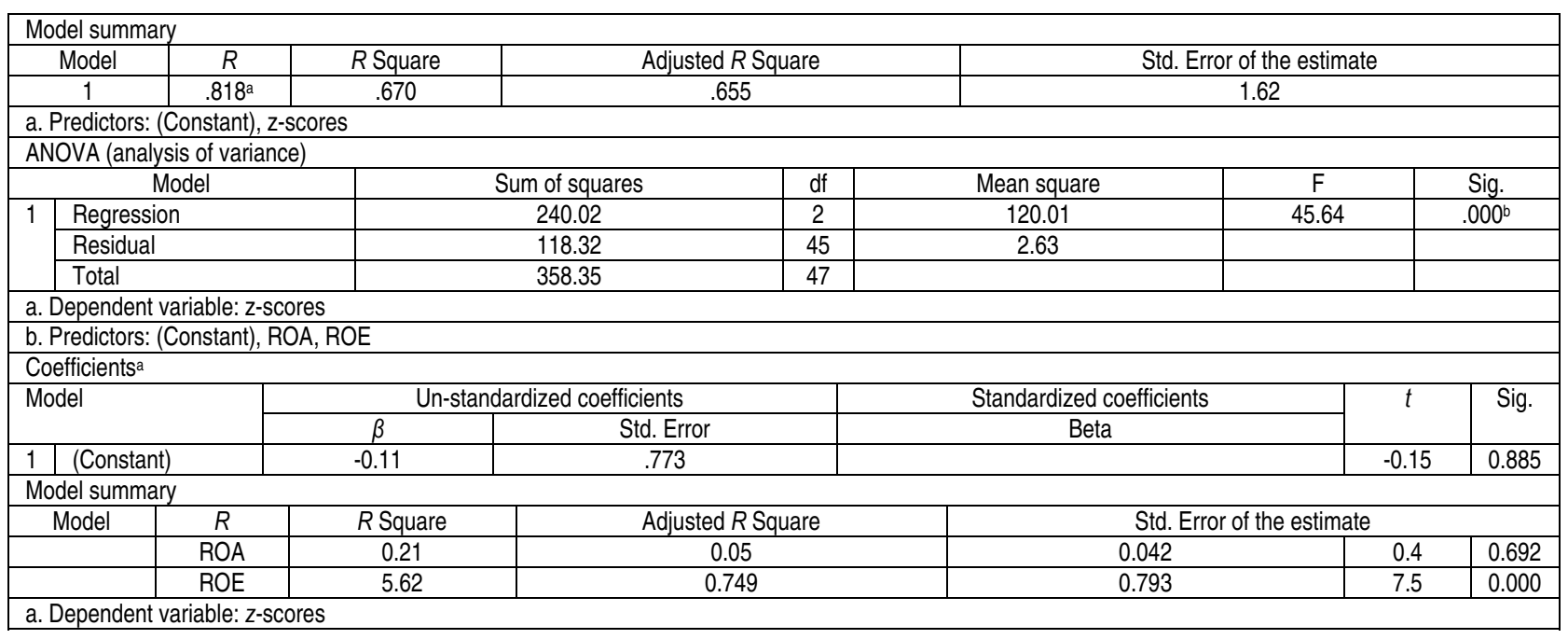

Proposition (4): Decreased financial performance resulted in increased misconduct. The data were obtained from the FSA and the FCA on fines imposed from 2002 to 2006 and from 2012 to 2015. Although numerous other authoritative bodies im- posed fines, only the data from these two authoritative bodies were used. Table 5 indicates the combined yearly amount $(\mathfrak{E})$ for all banks during the periods 2002 to 2006 and 2012 to 2015 . The results from Table 5 indicate that from the period 2002 to 
2006, the average amount of fines were $£ 17.0$ million ( $\mathrm{mn}$ ), where the average amount of fines between 2012 and 2015, a period which signifies dire economic conditions, as experienced by the aftermath of the credit crisis, amounts to $£ 891 \mathrm{mn}$. An increase of $£ 874 \mathrm{mn}$, which indicates that dire economic conditions and diminished financial performance, has resulted in increased misconduct. Hence, the alternative Proposition (4) can be accepted.

Table 4. FSA/FCA fines imposed on US and UK banks between 2002 and 2006

\begin{tabular}{|l|c|}
\hline \multicolumn{1}{|c|}{ Year } & Amount $(£)$ in millions \\
\hline 2002 & 7.4 \\
\hline 2003 & 10.0 \\
\hline 2004 & 24.0 \\
\hline 2005 & 16.0 \\
\hline 2006 & 13.0 \\
\hline Mean & 16.0 \\
\hline
\end{tabular}

Source: FSA (2015); FCA (2015).

Table 5. FSA/FCA fines imposed on US and UK between 2012 and 2015

\begin{tabular}{|l|c|}
\hline \multicolumn{1}{|c|}{ Year } & Amount $(£)$ in millions \\
\hline 2012 & 311 \\
\hline 2013 & 474 \\
\hline 2014 & 1471 \\
\hline 2015 & 171 \\
\hline Mean & 891 \\
\hline
\end{tabular}

Source: FSA (2015); FCA (2015).

\section{Conclusion}

In order to accept Proposition (1), an extensive literature review was conducted. The literature review confirmed that dire economic conditions resulted in increased competition, as there were reports of "champagne bonuses" and "a grand in your hand" for reac-hing targets. Furthermore, as a result of the credit crisis and, hence, declining profits, banks were forced to compete with the changing markets, as well as keep their profits high, as was experienced prior to the credit crisis.
Proposition (2) was accepted based on the resulting z-scores from seven international banks calculated from 2000 to 2006 and from 2007 to 2010 . The mean z-scores decreased from 5.47 to 1.41 in, which indicates increased risk taking. Proposition (3): Risk taking levels had an impact on bank's financial performance, was accepted only on the basis that the ROE was the only factor significantly impacted by the levels of risk taking. Proposition (4) was accepted based on the fines imposed by the FSA and the FCA, based on the presumption that increased fines are a result of increased misconduct. From the period 2002 to 2006, the mean fines imposed amounted to $£ 16 \mathrm{mn}$ and, from the period 2007 to 2015 , the mean fines amounted to $£ 891 \mathrm{mn}$ for an increase of $£ 874 \mathrm{mn}$.

\section{Implications and future direction for research}

Misconduct in trading has far-reaching implications for the financial institutions in which this occurs. First, it is costly. Trading losses, fines, settlements, capital provisions, litigation costs, and redress costs together build up to high "cost per case" that undermine business profitability, and deplete capital reserves. Second, there is reputational damage that negatively impacts business trust. The trust of the public, consumers, politicians, companies, in banks is at an ultimate low. Yet, trust is important to secure future sales and funding conditions. Negative consequences of misconduct can also be felt in their legal implications. Court rulings increasingly attend to the accountability of the bank involved, and the senior management overseeing the trader that behaved unethically.

Evidently, the "cost" of misconduct is high, however, this does not seem to diminish misbehaving, as such, one future direction for research is to analyze possible disciplinary actions against not only CEOs, but also senior management.

\section{References}

1. Abrantes-Mentz, R.M. \& Evans, D.S. (2012). Will The Wheatly Recommendations Fix Libor? Available at: http://ssrn.com. Accessed: 19/01/15.

2. Aebi, V., Sabato, G. \& Schmid, M. (2012). Risk management, corporate governance, and bank performance in the financial crisis, Journal of Banking and Finance, 36 (2012), pp. 3213-3226.

3. Athanasoglou, P.P., Brissimsis, S.N. \& Delis, M.D. (2008). Bank-specific, industry-specific and macroeconomic determinants of bank profitability, Journal of International Financial Markets, Institutions and Money, 18 (2), pp. 121-136.

4. BBC News. (2013). Timeline: Libor-fixing scandal. Available at: http://www.bbc.com. Accessed: 17/09/15.

5. BBC News. (2014). How the forex scandal happened. Available at: http://www.bbc.com. Accessed: 20/02/2015.

6. BBC News. (2014). Six banks fined $£ 2.6$ bn by regulators over forex failings. Available at: http://www.bbc.com. Accessed: 20/02/2015.

7. BBC. (2008). Timeline: Credit crunch to downturn. Available at: http://bbc.co.uk. Accessed: 08/06/15.

8. Beck, T. \& Laeven. (2006). Resolution of failed banks by deposit insurers cross-country evidence. World Bank Policy Research Working Paper No. 3920. 
9. Beyer, M., de Manza, D. \& Reyniers, D. (2013). Do financial advisor commissions distort client choice? Economic Letters, 119 (2), pp. 117-119.

10. Boot, A.W.A. \& Marnic, M. (2009). Competition and Entry in Banking: Implications for Capital Regulation. ACLE Working paper.

11. Brandao-Marques, L., Corrae, R. \& Sapriza, H. (2013). International evidence on government support and risktaking in the banking sector. International Finance Discussion Papers No. 1086, Board of Governors of the Federal Reserve System.

12. Bruner, C.M. (2011). Corporate governance reform in a time of crisis, The Journal of Corporation Law, 36 (2), pp. 309-341.

13. Brunnermeier, M.K. (2009). Deciphering the liquidity and credit crunch 2007 - 2008, Journal of Economic Perspectives, 23, pp. 77-100.

14. Campbell, J.Y. (2006). Household finance, Journal of Finance, LXI (4), pp. 1553-1604.

15. Campbell, J.Y., Jackson, H.E., Madrian, B.C. \& Tunafu, P. (2011). Consumer Financial Protection, Journal of Economic Perspectives, 25 (1), pp. 91-114.

16. Chiaramonte, L., Croci, E. \& Poli, F. (2015). Should we trust the Z-score? Evidence from the European Banking Industry, Global Finance Journal, 25, 99, pp. 111-131.

17. De Nicolo, G. (2000). Size, charter value and risk in banking: an international perspective. International Finance Discussion Papers No. 689, Washington, DC: Board of Governors of the Federal Reserve System.

18. Dell'Ariccia, G. \& Marquez, R. (2006). Lending Booms and Lending Standards, Journal of Finance, 61 (5), pp. 2511-2546.

19. Duchin, R., Ozbas, O. \& Sensoy, B.A. (2010). Costly external financial, corporate investment, and the subprime mortgage crisis, Journal of Financial Economics, 97 (2010), pp. 418-435.

20. Eisl, A., Jankowitsch, R. \& Subrahmanyam, M.G. (2013). Are interest rate fixings fixed? An analysis of LIBOR and EURIBOR. Meielisalp Workshop and Summer School, Leissigen, Schweiz, 30.06-04.07.

21. Erkens, D.H., Hung, M. \& Matos, P. (2012). Corporate governance in the 2007-2008 financial crisis: Evidence from financial institutions worldwide, Journal of Corporate Finance, 18 (2), pp. 389-411.

22. Evanoff, D.D. \& Ors, E. (2008). The competitive dynamics of geographical deregulation in banking: implications for productive efficiency, Journal of Money, Credit, and Banking, 40 (5), pp. 897-928.

23. FCA. (2012). FCA fines five banks $£ 1.1$ billion for FX failings and announces industry-wide remediation programme. Available at: https://www.fca.org.uk. Accessed: 19/10/15.

24. FCA. (2015). Monthly PPI refunds and compensation. Available at: https://www.fca.org.uk. Accessed: 19/10/15.

25. Ferran, E. (2011). The break-up of the Financial Services Authority, Oxford Journal of Legal Studies, pp. 1-26.

26. FSA. (2012). Financial Services Authority: Final Notice. Available at: http://www.fsa.gov.uk/. Accessed: 19/10/15.

27. Fukuda, S. (2012). Market-specific and currency-specific risk during the global financial crisis: Evidence from the interbank markets in Tokyo and London, Journal of Banking \& Finance, 36 (2012), pp. 3185-3196.

28. Garcia-Harrero, A., Gacila, A. \& Santabarbra, D. (2009). What explains low profitability of Chinese banks? Journal of Banking and Finance, 33 (11), pp. 2080-2092.

29. Goodway, N. (2014). Forex scandal: why and how traders rigged the foreign exchange market. Available at: http://www.independent.co.uk. Accessed: 20/02/2015.

30. Gottesman, A. (2016). Derivatives Essentials: An introduction into Forwards, Futures, Options, and Swaps. Wiley \& Sons, Hoboken, USA.

31. Guardian. (2008). Credit crunch: Market turmoil. Available at: http://www.guardian.co.uk. Accessed: 08/06/15.

32. Hannan, T.H. \& Hanweck, G.A. (1998). Bank solvency risk and the market for large certificates of deposit, Journal of Money, Credit, and Banking, 20 (2), pp. 203-211.

33. Hasan, I. \& Marinc, M. (2013). Should competition policy in banking be amended during crises? Lessons from the EU, European Journal of Law and Economics, 1.

34. Inderst, R. (2009). Retail Finance: Thoughts on Reshaping Regulation and Consumer Protection after the Financial Crisis, European Business Organization Law Review, 10, pp. 455-464.

35. Ivashina, V. \& Scharfstein, D. (2010). Bank lending during the financial crisis of 2008, Journal of Financial Economics, 97 (2010), pp. 319-338.

36. Mullainathan, S., Noeth, M. \& Schoar, A. (2012). The Market for Financial Advice: An Audit Study. Working paper 17929, NBER.

37. Rhodes, W. (2015). Guest view: Banks need to lead on cultural change. Available at: http://banking.einnews.com. Accessed: 05/02/15.

38. Roy, A.D. (1952). Safety first and holding of assets, Econometrica, 20, pp. 431-449.

39. Ryder, N. (2014). The good, the bad and the downright ugly, Criminal Lawyer, 221, pp. 5-6.

40. Stiroh, K.J. \& Stahan, P.E. (2003). Competitive Dynamica of Deregulation: Evidence from US Banking, Journal of Money, Credit, and Banking, 35 (5), pp. 801-828.

41. World Bank. (2015). World Development Indicators. Available at: http://databank.worldbank.org. Accessed: $19 / 09 / 15$. 